\title{
TELAAH KRITIS PEMIKIRAN ABDUL MANNAN TENTANG RIBA DAN BUNGA BANK
}

\author{
Annisa Eka Rahayu \\ Magister Ekonomi Syariah, Pascasarjana Universitas Islam Bandung \\ Email: annisaeka1397@gmail.com \\ Nunung Nurhayati \\ Magister Ekonomi Syariah, Pascasarjana Universitas Islam Bandung \\ nunungunisba@yahoo.co.id
}

\begin{abstract}
The understanding of the Muslim community on usury and bank interest is very diverse. On one hand, people assume that bank interest is haram, but on the other hand there are those who assume that bank interest must be paid. usury and bank interest are two dimensions of the same nature, but there are those who use the reason that interest is not usury. In this writing, we will discuss how a contemporary figure, Muhammad Abdul Mannan, thought about usury and bank interest. Abdul Manan mentioned that bank interest is part of usury. This research can be based on a normative juridical approach, namely by studying or analyzing secondary data, the research specifications used are descriptive analytical and data collection methods used are library studies, namely by studying and analyzing books and literature relating to the object of discussion. The purpose of this research is for the reader to know and study Mannan's opinion and be able to reflect his thoughts with current actual reality.
\end{abstract}

Keywords: ; Riba, Interest, and Abdul Mannan

\begin{abstract}
Abstrak
Pemahaman masyarakat Muslim terhadap riba dan bunga bank sangatlah beragam. Di satu sisi, masyarakat berasumsi bahwa bunga bank itu haram, namun di sisi lain ada yang berasumsi bahwa bunga bank wajib dibayarkan. riba dan bunga bank merupakan dua dimensi yang sifatnya sama, namun adapun yang memakai alasan bahwa bunga itu bukan riba. Dalam penulisan ini, akan dibahas bagaimana pemikiran seorang tokoh kontemporer yaitu Muhammad Abdul Mannan, mengenai riba dan bunga bank. Abdul Manan menyebutkan bahwa bunga bank adalah bagian dari riba. dapat meng Penelitian ini berdasarkan kepada pendekatan yuridis normatif, yaitu dengan mengkaji atau menganalisis data sekunder, spesifikasi penelitian yang digunakan adalah deskriptif analitis dan Metode pengumpulan data yang dipergunakan adalah studi kepustakaan, yaitu dengan mengkaji dan menganalisis buku dan literature-literatur yang berkaitan dengan objek pembahasan. Tujuan dari penelitian ini, agar pembaca mengetahui dan mengkaji pendapat Mannan serta dapat direlevansikan pemikirannya dengan kenyataan actual saat ini.
\end{abstract}

Kata Kunci: Riba, Bunga Bank, dan Abdul Mannan 


\section{Dasar Pemikiran}

Islam merupakan agama komprehensif yang senantiasa salih li hull az-zaman wa al-makan. Islam mencakup seluruh aspek kehidupan manusia (kaffah). Mulai dari urusan pribadi hingga urusan kemasyarakatan, dari aspek ibadah hingga aspek muamalah, atau aspek yang berhubungan terkait dengan hablun min Allah (hubungan dengan Allah), maupun hubungan hablun mun al-nas (hubungan dengan manusia). Di antara aspek tersebut ajaran Islam mengatur muamalah (H. Aravik, 2020).

Melakukan kegiatan ekonomi dalam bingkai akidah maksudnya adalah usaha yang dilakukan seseorang Muslim harus dimaknai dalam rangka ibadah dan sarana mendekatkan diri (taqarrub) kepada Allah Swt. Salah satu tuuan aktivitas ekonomi adalah merupakan tabiat manusia untuk memenuhi kehidupannya, dengan itu ia nenperoleh risky dan dengan risky ua dakao melangsungkan kehidupannya (Zuhri, 1997). Islam mengatur peredaran uang, mekanisme pasar, perdagangan, sewa guna dan pinjam meminjam. Islam melarang unsur riba dalam melakukan kegiatan ekonomi karena menimbulkan perekonomian yang tidak sehat dan merugian banyak pihak. System ekonomi tidak dapat dipisahkan dari lembaga intermediasi keuangan (financial intermediary institution) yang memang sangat dibutuhkan msayarakat. Namun, selam sekian ratus tahun umat Islam terbiasa dengan pelayanan bank konvensional yang berbasis bunga, sehingga memerlukan kerja keras untuk merujudkan alternatifnya yang bebas bunga yaitu dengan mengembangkan perbankan syariah (Qardhawi, 2002).

Sesungguhnya muamalah ribawi telah mewabah dan mengakar di tengah-tengah kaum muslimin, hamper semua kalangan mempraktikannya, mulai dari perorangan hingga lembaga, mulai dari rakyat hingga Negara. Kegiatan ekonomi dari masa ke amasa mengalami perkembangan. Yang dahulu tidak ada, menjadi ada ataupun sebaliknya. Di masa Rasulullah tidak ada, dan kini ada. Persoalan baru dalam fikih Mu'amalat muncul ketika pengertian riba sebagaimana diketahui pada persoalan bank. Di suatu pihak, bunga bank terperangkap dalam kriteria riba, tetapi di sisi lain bunga bank mempunyai sisi social yang besar bahkan, dapat dikatakan tanpa bank suatu Negara akan hancur. 
Bunga bank menimbulkan pro dan kontra di kalangan umat Islam, khususnya Indonesia. Berbagai Organisasi ke Islaman di Indonesia tidak menyatakan halalnya bunga bank. Namun adapula sebagian yang menyatakan bolehnya manfaat bunga bank. Kelihatannya, perbedaaan pandangan ini terjadi karena 'iilat riba yang diajukan oleh para fuqaha'. Sementara, berbagai perkembangan menyangkut kegiatan ekonomi dewasa ini, seperti perubanhan nilai tukar uang dan peranan bank dalam pengamanan uang dan penyediaan dana tidak termasuk perhatian kajian fikih. Ada orang yang berpendapat bahwa al-Qur'an hanya melarang riba dalam bentuk bunga berbunga (compound interest) dan bunga yang dipraktikan oleh bank konvesnional bukan iba. Namun jumhur ulama mengatakan bahwa bunga bank adalah riba. Sebagaimana yang dijelaskan oleh Allah Swt. Dalam firman-Nya Q.S. al-Baqarah [2]: 278:

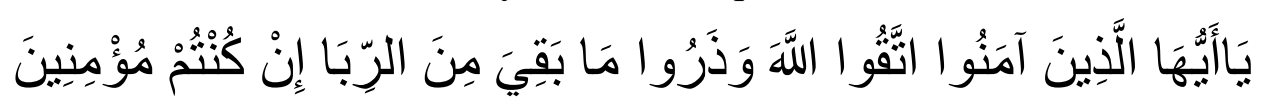

"Wahai orang-orang yang beriman! Bertakwalah kepada Allah dan tinggalkan sisa riba (yang belum dipungut) jika kamu oran beriman."

Namun tetap saja ekonomi secara umum berpilar riba. Transaksi riba dianggap sesuatu yang lumrah, bukan sebuah dosa dan kejahatan, bahkan hukum begara melegalkan dan memayunginya. Pemakan riba dan pemberi makan riba tidak dipandang sebagai pendosa yang dikutuk di masyarakat. Bahkan sebgaian kalangan menjadikan riba sebagai salah satu sumber penghidupan mereka, baik melalui tabungan atupun deposito. Pelakunya memakan bunga (riba) dengan tenang dan nyaman tanpa merasa berdosa sedikit pun dan msyarakat secara umum memandangnya sebagai suatu hal yang lumrah (Khair, 2017).

Sungguh itu merupakan sebuah potret kehidupan yang sangat bertentangan dengan Islam. Islam mengharamkan riba, termasuk Islam mewajibkan pemerintah melarang melakukan praktik riba, karena riba merupakan kejahatan yang berimplikasi pada masyarakats ecara keseluruhan. Apabila ada seseorang atau kelompok tetap melakukan riba secara sengaja, maka pemerintah berhak untuk melarangnya (Nawawi, 2019). Hal ini karena Allah Swt memasukannya ke dalam deretan dosa-dosa besar, mengutuk pelakunya dan mengecam dengan berbagai bentuk hukuman di dunai dan di akhirat. 
50 | Annisa Eka Rahayu, Nunung Nurhayati, TELAAH KRITIS PEMIKIRAN ABDUL MANNAN TENTA..........

Dalam hal ini penulis akan membahas pendapat salah seorang tokoh yaitu Abdul Mannan, terkait pendapatnya mengenai riba dan bunga bank, maka dari itu penulis artikel ini dengan judul "Telaah Kritis Pendapat Abdul Mannan Tentang Riba dan Bunga Bank"

\section{Metode Penelitian}

Metode penelitian berdasarkan kepada pendekatan yuridis normatif, yaitu dengan mengkaji atau menganalisis data sekunder yang berupa bahan-bahan hukum sekunder dengan memahami hukum sebagai perangkat peraturan atau norma positif di dalam perundang-undangan yang berlaku, jadi penelitian ini dipahami sebagai penelitian kepustakaan, yaitu penelitian terhadap bahan sekunder (Mamudji, 2018). Spesifikasi penelitian yang digunakan adalah deskriptif analitis, yaitu penelitian untuk menggambarkan masalah yang ada pada masa sekarang (masalah yang aktual), dengan mengumpulkan data, menyusun, mengklasifikasikan, menganalisis, dan menginterpretasikan. Jenis data yang dipergunakan dalam peneitian ini, yaitu data sekunder, yakni berupa berupa literature-literatur pendukung yang berkaitan dengan Riba dan Bunga Bank. Metode pengumpulan data yang dipergunakan adalah studi kepustakaan, yaitu dengan mengkaji dan menganalisis buku dan literature-literatur yang berkaitan dengan Riba dan Bunga Bank. Metode analisis data yang digunakan dalam penelitian ini adalah metode kualitatif. Analisis terhadap data sekunder yang bersifat kualitatif tersebut dilakukan dengan cara berlandaskan pada teori hukum ataupun doktrin hukum yang terdapat pada kerangka pikir, yang dapat diterapkan pada fokus permasalahan.

\section{Pembahasan}

\section{Riwayat Hidup Muhammad Abdul Mannan}

Muhammad Abdul Mannan adalah seorang pencetus ekonomi Islam. Karyanya yang terkenal "Islamic Economic: Theory and Practice" diterbitkan pada tahun 1970, tiga tahun sebelm Konferensi Ekonomi Islam I di Mekkah yang melahirkan Islamic Development Bank (IDB). Karya ini mengilhami banyak penulisan tentang ekonomi dan perbankan Islam di beberapa negara. Tidak puas menghadirkan teori tentang P-ISSN : 2460-9595

E-ISSN : 2686-5149

DOI. 10.36908/isbank 
ekonomi Islam. Manan kemudian terlibat dalam pembentukan social Investment Bank pada tahun 1996 di Bangladesh. Di antara produk yang terkenal di lembaga ini adalah Cash Waqf Certificate yang di Indonesia dikembangkan dengan nama Sertifikat Wakaf Tunai (Hakim, 2011).

Muhammad Abdul Mannan dilahirkan di Bangladesh, pada tahun 1918. Mannan menikah dengan seorang wanita bernama Nargis Mannan yang bergelar master di bidang ilmu politik (H. Aravik, 2017). Ia merupakan seorang tokoh ekonomi Islam yang menjadi menganjurkan pembentukan Bank Dunia Islam Muslim Wordl Bank, lima tahun sebelum pembentukan sesungguhnya dari Iskamic Development Bank (IDB) pada tahun 1975 di Jeddah, Arab Saudi.

Abdul Mannan meraih gelar master di bidang ekonomi dari Rajshahi University pada tahun 1960. Setelah menerima gelar master di bidang ekonomi, ia bekerja di berbagai kantor ekonomi pemerintahan di Pakistan, di antaranya sebagai Asisten Pimpinan di the Federal Planning Commission of Pakistan pad atahun 1960-an. Pada tahun 1970, Abdul Mannan melanjutkan studinya di Michgan State University, Amerika Serikat untuk program MA dalam ilmu ekonomi. Setelah mendapat gelar MA (economic) pad atahun 1973, Abdul Mannan mengambil program doktor di bidang industri dan keuangan pada universitas yang sama (Haneef, 1995).

Setelah menyelesaikan program doktornya, Mannan menjadi dosen senior dan aktif mengajar di Papua New Guinea Univesrsity of Technology. Di sana ia juga ditunjuk sebagai pembantu dekan. Pada tahun 1978, ia ditunjuk sebagai profesor di Internasional Centre fo Research in Islamic Economics, universitas King Abdul Aziz di Jeddah. Selama periode tersebut, Mannan juga aktif sebagai visiting profesor pada Moeslim Institute di London dan Georgetown University di Amerika Serikat. Melalui pengalaman akademiknya yang panjang, Mannan memutuskan bergabung dengan Islamic Development Bank dan sejak 1984 menjadi ahli ekonomi (Islam) senior di IDB (Muhamad, 2019).

Selama 3 tahun karirinya, Mannan telah banyak sekali berperan dalam sejumlah besar organisasi pendidikan dan ekonomi. Pada tahun 1970, ia menerbitkan buku utamanya yang pertama, yakni Islamic Economic Theory and Practice. Buku ini P-ISSN : 2460-9595 
dipandang oleh kebanyakan mahasiswa dan sarjana ekonomi Islam sebagai "buku teks" pertama ekonomi Islam. Buku tesebut mendapatkan pengakuan internasional dan telah diterbitkan sampai 12 kali, direvisi pada tahun 1986, serta telah diteremahkan ke dalam bahasa Arab, Turki, Benggali dan Malaysia (dan Indonesia, pent). Untuk sumbangannya bagi pengembangan ekonomi Islam, Mannan dianugerahi "Highest Acadmic Award of Pakistan” pada tahun 1974 yang bagi Mannan. Serta dengan hadiah Pulitzer. Pada tahun 1970, ekonomi Islam berada dalam tahapan pembentukan, berkembang dari pernyataanpernayataan tentang prinsip ekonomi secara umum dalam Islam, hingga uraian yang lain haruslah dicatat bahwa pada saat iu tidak ada satu universitas pun yang mengajarkan ekonomi Islam seperti sekarang, yakni suatu zaman ketika fiqh muamalah (hukum bisnis) masih dipandang sebagai ekonomi Islam (Haneef, 2010).

Seiring dengan berlalunya waktu, ekonomi Islam berkembang baik mengenai kedalamnnya ruang lingkupnya, ditandai oleh banyaknya buku yang ditulis orang dan diajarkannya ekonomi Islam ini di tingkat universitas. Hal ini mendorong Mannan untuk menerbitkan dua buku lagi di tahun 1984, yakni The Making of Islamic Economic Society dan The Frontiers of Islamic Economic, menurut Mannan, dapat dipandang sebagai upaya yang lebih serius dan terinci dalam menjelaska bukunya yang pertama. Tak dapat disangkal bahwa Mannan telah menyumbang bagi pengembangan literatur ekonomi Islam, dan oleh karenanya, karya-karyanya dianalisis sebagai bagian dari studi kita mengenai pemikiran ekonomi Islam kontemporer ini.

Selain karya-karya Mannan yang telah disebutkan di atas, sebagai ilmuwan dan sekaligus akademisi, Abdul Mannan telah menulis sejumlah buku lainnya, yaitu: An Introduction to Appied Economic (1963), Economic Probleum and Planning in Pakistan (1968), The Making of Islamic Economic Society: Islamic Dimensions in Economic Developtemen and Social Peace in Islam (1989), Management of Zakah in Modern Society (1989), Developing a System of Islamic Financial Instrumen (1990), Understanding Islamic Finance: A Study of Security Market in an Islamic Framework (1993), International Economic Relation from Islamic Perspective (1992), Structural Adjustments and Islamic Voluntary sector with special refreence to Bangladesh (1995), 
ISLAMIC BANKING: Jurnal Pemikiran dan Pengembangan Perbankan Syariah, Volume 6 Nomor 1 Edisi Agustus 2020

The Impact of Single European Market on OIC Member Countries (1996) dan Financing Development in Islam (1996) (Janwari, 2016).

\section{Konsep Riba}

Ditinjau dari ilmu bahasa Arab, riba secara bahasa berasal dari kata rabaayarbuu (ربا- يربو) yang artinya "tumbuh dan bertambah". Riba bermakna الزيادة مطلقاً (tambahan yang mutlak). Firman Allah Ta'ala dalam Q.S al-Hajj [22] : 5 berikut merupakan contoh nyata akan penggunaan kata riba dalam pengertian semacam ini:

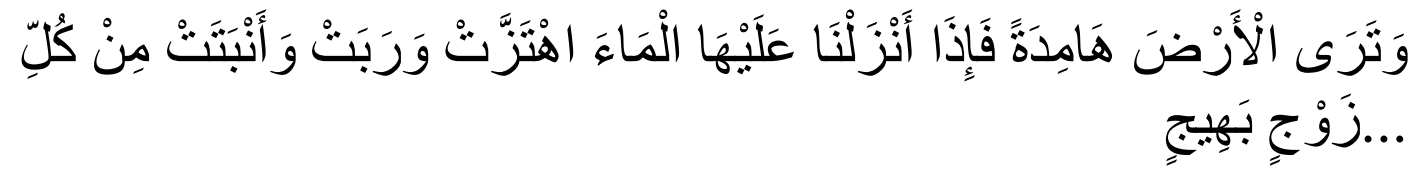

“... Dan kamu lihat bumi ini kering, kemudian apabila telah Kami turunkan air di atasnya, hiduplah bumi itu dan suburlah dan menumbuhkan berbagai macam tumbuh-tumbuhan yang indah."

Ibnu Katsir tetkala menfsirkan ayat berkata, "Bila Allah telah menurunkan hujan ke bumi, maka bui bergerak dengan menumbuhkan tumbuhan dan tanah yang sebelumnya mati (gersang) menjadi hidup, lalu barang batangnya menjulang tinggi dari permukaan tanah. Dan dengan hujan Allah, menumbuhkan berbagi rupa macam buahbuahan, tanaman, tumbuh-tumbuhan dengan beraneka ragam warna, rasa, aroma, bentuk dan kegunaannya.

Menurut Quraish Shihab, kata riba dari segi bahasa berarti "kelebihan”. Kalau kita hanya berhenti pada makna kebahasaan ini, maka logika yang dikemukakan para penentang riba pada masa Nabi dapat dibenarkan. Ketika itu mereka berkata (sebagaimana diungkapkan al-Qur"an -bahwa "jual beli sama saja dengan riba" (QS. alBaqarah [2]: 275), Allah menjawab mereka dengan tegas bahwa "Allah menghalalkan jual beli dan mengharamkan riba". Penegasan ini dikemukakan-Nya tanpa menyebut alasan secara eksplisit, namun dapat dipastikan bahwa tentu ada alasan atau hikmah sehingga riba diharamkan dan jual beli dihalalkan (Ghofur, 2016).

Adapun dalam pandangan syari'at maka para ulama berbda-beda pendpaat dalam mendefiniskan, akan tetapi maksud dan maknanya tidak jauh berbeda. Dalam kaitannya 

dengan pengertian al-bathil dalam Ayat tersebut, Ibnu al-Arabi al-Maliki dalam kitabnya, Ahkam Al-Quran, menjelaskan,

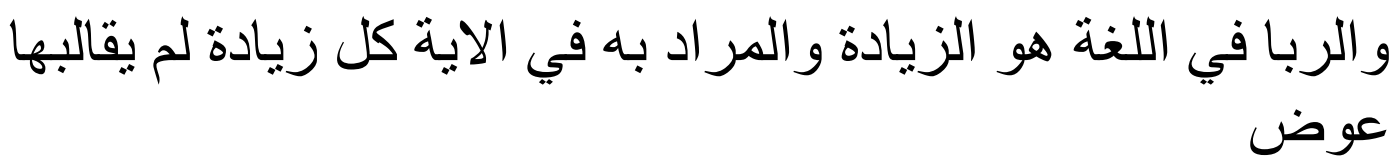

"Pengertian riba secara bahasa adalah tambahan, namun yang di maksud riba dalam ayat Al-Quran yaitu setiap penambahan yang diambil tanpa ada satu transaksi pengganti atau penyeimbang yang dibenarkan syari'ah)".

Adapaun pengertian riba secara etimologis menurut para ulama adalah:

Ulama Hanabilah

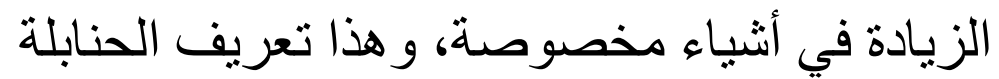

"Pertambahan sesuatu yang dikhususkan, ini adalah definisi ulama Hanabilah” (Al-Zuhaili, 2009).

Ulama Hanafiah

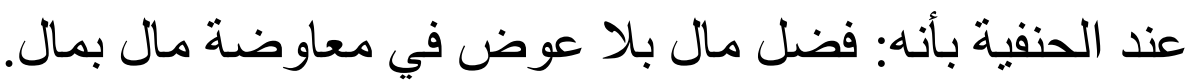

"Tambahan pada harta pengganti dalam pertukaran harta dengan harta".

Riba juga berarti tumbuh dan membersar. Adapun dalam istlah teknis, riba berarti pemngmbilan tambahan dari harta pokok tanpa adanya kompensasi (Sobana, 2018). Diantara definisi yang saya rasa cukup mewakili berbagai definisi yang ada ialah bahwa riba merupakan suatau akad atau transaksi atau barang tertentu yang ketika akad berlangsung, tidak diketahui kesamaannya menurut ukuran syariah atau dengan menunda penyerahan ketika barang yang menjadi objek akad atau salah satunya (Badri, 2018).

\section{Jenis-jenis Riba}

Secara garis besar, riba dikelompokan menjadi dua, masing-masing adalah riba utang-piutang dan riba jual beli. Kelompok pertama terbagi lagi menjadi riba qardh dan riba jahiliah. Adapun kelompok kedua, riba jual beli, terbagi menjadi riba fadhl dan riba nasi'ah (P. Adam, 2017).

Jenis riba dalam hal ini dibagi menjadi dua bagian, yakni riba dalam dalm jual beli (buyu') dan riba dalam utang putang (duyun). Riba jual beli dibagi menjadi dua bagian 
yaitu riba nasi'ah dan riba fadhl. Sedangkan riba dalam utang piutang dibegai menjadi dua macam pula yakni riba qardh dan riba jahiliyah. Berikut penjelasannya.

1. Riba yang termasuk ke dalam riba jual beli (buyu').

a. Riba nasi'ah, adalah penyerahan atau penerimaan jenis barang ribawi yang dipertukarkan dengan jenis barang ribawi lainnya. Riba nasi'ah muncul karena adanya perbrdaan, perubahan, atau tambahan antara yang diserahkan saat ini dan diserahkan kemudian.

b. Riba fadhl, adalah menukar salah satu jenis barang riba dengan jenis barang yang sama dan salah satunya lebih berat atau lebih banyak dari lainnya. Seperti $5 \mathrm{~kg}$ beras kualitas tinggi ditukar dengan $7 \mathrm{~kg}$ beras berkualtias rendah, kelebihan $2 \mathrm{~kg}$ dalam transaksi ini adalah riba fadhl.

2. Riba yang termasuk ke dalam riba utang-piutang (duyun).

a. Riba qard, adalah adanya tambahan yang disyaratkan dalam perjanjian.

b. Riba jahiliyah adalah tambahan yang disyaratkan dan diambil oleh orang yang meminjamlkan dari orang yang diberi pinjaman, sebagai imbangan penundaan pembayaran utang atau utang dibayar lebih dari pokoknya karena si peminjam tidak mampu membayar utangnya pada waktu yang ditetapkan (N. N. dan P. Adam, 2015).

\section{Tafsir dan Historisitas Ayat Riba}

Larangan riba yang terdapat dalam Al-Quran tidak diturunkan sekaligus melainkan diturunkan dalam empat tahap (Antonio, 2007).

Tahap pertama, menolak anggapan bahwa pinjaman riba yang pada dzahirnya seolah-olah menolong mereka yang memerlukan sebagai suatu perbuatan mendekati atau taqarrub kepada Allah Swt.

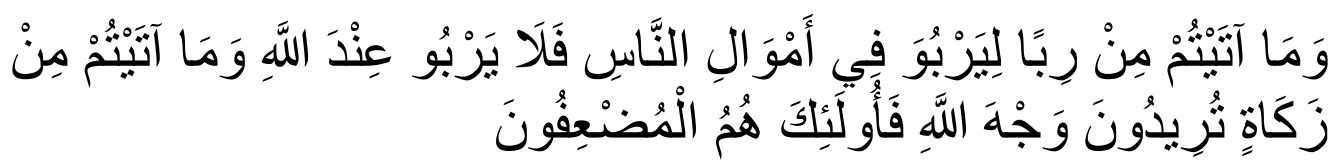

'Dan sesuatu riba (tambahan) yang kamu berikan agar dia bertambah pada harta manusia, maka riba itu tidak menambah pada sisi Allah. Dan apa yang kamu berikan 
56 | Annisa Eka Rahayu, Nunung Nurhayati, TELAAH KRITIS PEMIKIRAN ABDUL MANNAN TENTA..........

berupa zakat yang kamu maksudkan untuk mencapai keridaan Allah, maka (yang berbuat demikian) itulah orang-orang yang melipat gandakan (pahalanya). "

Ayat ini diturunkan di Mekah sebelum Nabi Hijrah, yang pada zahirnya tidak ada isyarat yang menunjukkan diharamkannya riba itu. Tetapi, yang ada isyarat akan kemurkaan Allah terhadap riba itu, dimana dinyatakan, riba itu tidak ada pahalanya disisi Allah, jadi dengan demikian ayat ini berupa bentuk peringatan supaya erhenti dari perbuatan riba (Mukaromah, 2004). Ayat tersebut dinilai oleh ulama tafsir tidak berbicara tentang riba yang diharamkan, al-Qurtubhi menamakan riba yang dibicarakan pada ayat tersebutsebagai riba halal. Sedangkan Ibn Katsir menamainya dengans ebutan riba mubah. Adanya penafsiran tersebut, karena mereka merujuk kepada sahabat Nabi Saw, terutama Ibn 'Abbas dan beberapa tabi'in yang menafsirkan riba dalam ayat tersebut sebagai hadiah yang dilakukan oleh orang-orang yang mengharapkan imbalan lebih.

Tahap Kedua, Allah memberikan isyarat akan keharaman riba (Rozalinda, 2016) melalui kecaman terhadap praktik riba di kalangan asyarakat Yahudi. Hal ini diteaskan dalam Q.S an-Nisa [4]: 161.

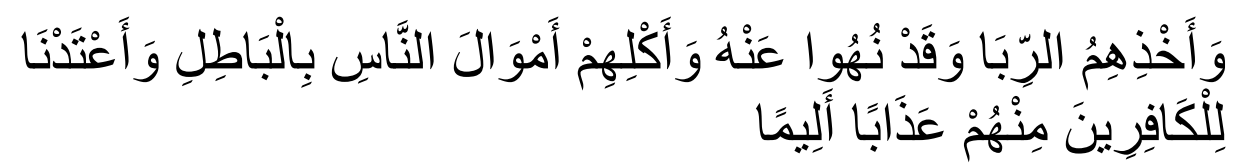

"Dan disebabkan mereka memakan riba, padahal sesungguhnya mereka telah dilarang daripadanya, dan karena mereka memakan harta orang dengan jalan yang batil. Kami telah menyediakan untuk orang-orang yang kafir di antara mereka itu siksa yang pedih."

Ayat ini diturunkan di Madinah dan merupakan pelajaran yang dikidahkan Allah tentang perilaku Yahudi kepada kita yan dilakarang melakukan riba, tetapi mereka justru yang memakannya, bahkan menghalalkannya. Maka sebagai akibat dari perbuatannya itu, mereka mendapat laknat dan kemurkaan Allah Swt. jadi larangan riba di sini baru berbentuk isyarat, bukan dengan terang-terangan. Sebab ini adalah kisah orang-orang Yahudi yang bukan merupakan dalil qath'i (pasti dan tetap) terkait pengharaman riba bagi kaum Muslimin (Ash-Shabuni, 2016).

Tahap Ketiga, Allah tidak mengharamkan riba secara tuntas, tetapi melarang dalam bentuk lipat ganda. Sebagaimana digambarkan dalam Q.S Ali-Imran [3] : 130. 
Hal ini meneggambarkan kebijaksanaan Allah yang melarang sesuatu yang telah mendarah daging, mengakar pada masyarakat sejak zaman jahliyah dulu, sedikit demi sedikit (step by step), sehingga mereka yang telah biasa melakukan riba siap menerimanya.

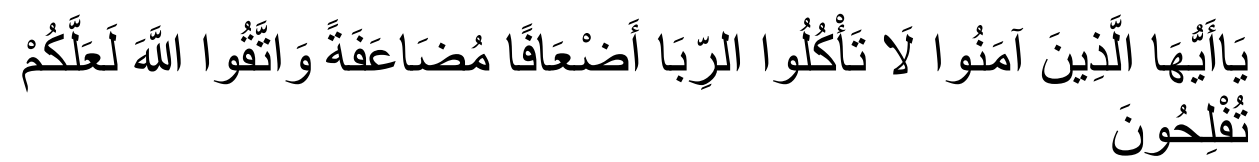

“ Hai orang-orang yang beriman, janganlah kalian memakan riba yang berlipat ganda dan bertakwalah kepada Allah supaya kamu mendapatkan keberuntungan."

Ayat ini diturunkan di Madinah dan merupakan larangan secara tegas. Akan tetapi, larangan haramnya di sini adalah satu macam dari riba yang (memamng disebut fahisy (riba yang paling keji), yaitu suatu bentuk riba yang paling jahat yang karenanya hutang ditanggung berlipat gandakarena pengutang hanya mengutang karena memang butuh dan terpaksa.

Ahmad Mustafa al-Maraghi dalam menafsirkan ayat 130 surat Ali- Imran ini, megutip uraian Ibn Jarir sebagai berikut:

" Janganlah kalian makan riba berlipat ganda dalam Islam, sesudah Allah memberikan petunjuk kepada kalian seperti yang biasa lakukan pada jaman Jahiliyah. Dalam masa Jahiliyaj seseorang melakukan riba berlipat ganda ini dengan cara memberikan utang kepada orang lain dengan masa pembayaran yang disebukan waktunya. Bila waktu pembayaran telah tiba, yang berpiutang akan meminta kepada yang berutang dan pembayaran uangamu, nanti aku tambah lagi", keduanya menyetujui hal ini, itulah yang dinamakan berlipat ganda. Kemudian Allah Swt mencegah melakukannya dalam agama Islam."

Tahap Keempat, Allah menurunkan Q.S al-Baqarah [2] : 275-276, 278-279 yang isinya tentang pelarangan riba secara tegas dan jelas, dalam berbagai bentuknya tidak dibedakan besar atau kecilnya dan tidak membedakan banyak atau sedikitnya . Bagi yang melakukannya maka ia telah mekakukan tidakan kriminalisasi. Dan ini adalah merupakan ayat yan terakhir turun, yang merupakan syariat yang terakhir pula. Dalam ayat ini jika seseorang melakukan transaksi riba, makan Allah dan Rasul-Nya akan memerangi orang tersebut. 


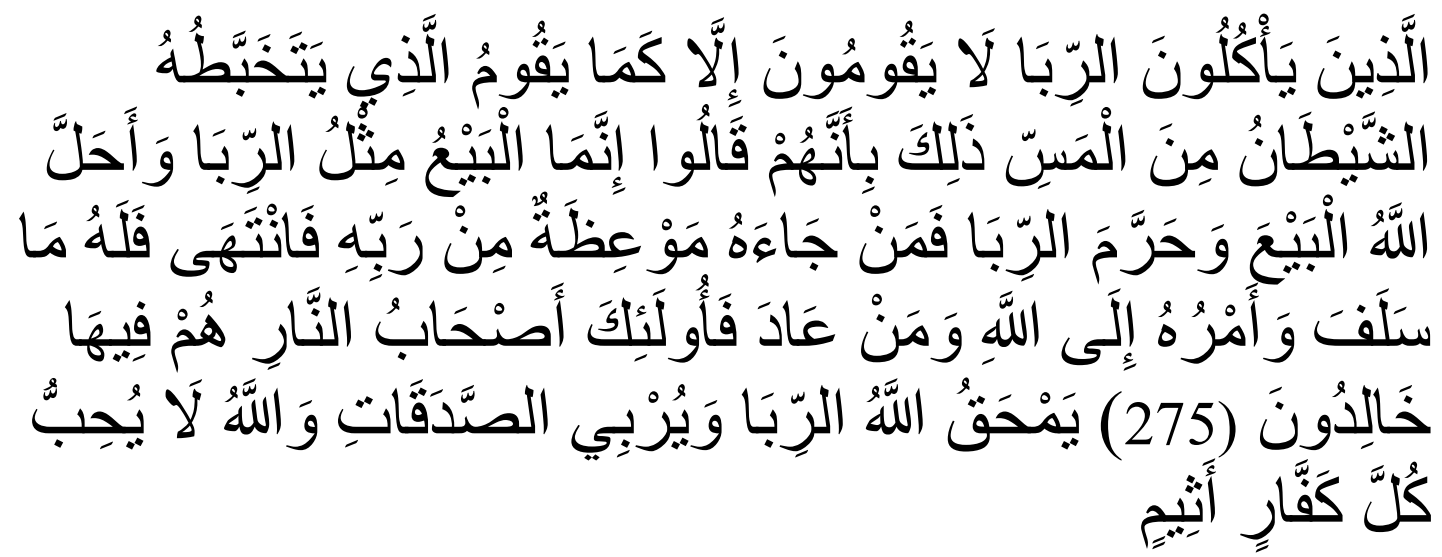

"Orang-orang yang makan (mengambil) riba tidak dapat berdiri melainkan seperti berdirinya orang yang kemasukan syaitan lantaran (tekanan) penyakit gila. Keadaan mereka yang demikian itu, adalah disebabkan mereka berkata (berpendapat), sesungguhnya jual beli itu sama dengan riba, padahal Allah telah menghalalkan jual beli dan mengharamkan riba. Orang-orang yang telah sampai kepadanya larangan dari Tuhannya, lalu terus berhenti (dari mengambil riba), maka baginya apa yang telah diambilnya dahulu (sebelum datang larangan); dan urusannya (terserah) kepada Allah. Orang yang mengulangi (mengambil riba), maka orang itu adalah penghuni-penghuni neraka; mereka kekal di dalamnya.(275) Allah memusnahkan riba dan menyuburkan sedekah. Dan Allah tidak menyukai setiap orang yang tetap dalam kekafiran, dan selalu berbuat dosa.(276)" (Q.S. al-Baqarah [2] : 275-276).

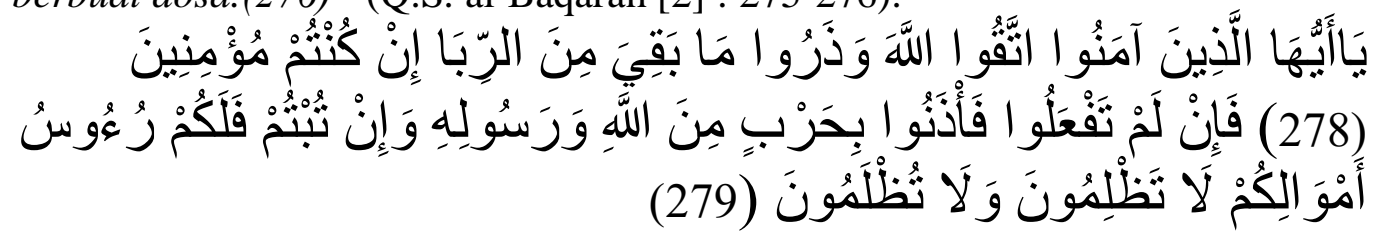

"Hai orang-orang yang beriman, bertakwalah kepada Allah dan tinggalkan sisa riba (yang belum dipungut) jika kamu orang-orang yang beriman. Maka jika kamu tidak mengerjakan (meninggalkan sisa riba), maka ketahuilah, bahwa Allah dan Rasul-Nya akan memerangimu.(278). Dan jika kamu bertobat (dari pengambilan riba), maka bagimu pokok hartamu; kamu tidak menganiaya dan tidak (pula) dianiaya.(279). (Q.S. al- Baqarah [2] : 278-279).

\section{Hadits-hadits yang Berkenaan dengan Riba}

Hadits-hadits yang menerangkan tentang riba cukup banyak, tetapi pada dasarnya hadits-hadits mengenai riba tersebut dapat dibagi kepada empat golongan. 
1. Hadits yang mekarang riba secara umum.

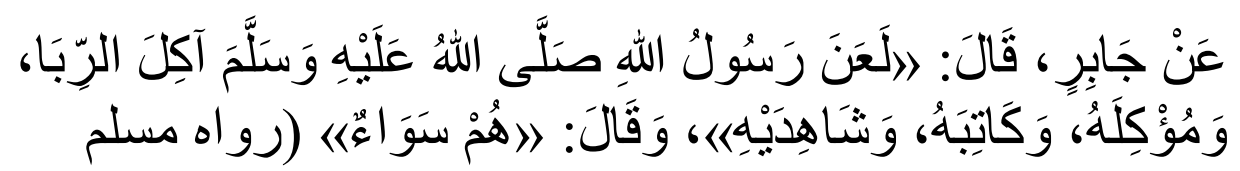

Dari Jabir r.a Ia berkata : Allah melaknat orang pemakan riba, wakilnya, penulisnya, dan dua saksinya. Beliau bersabda, "Mereka itu sama." (H.R. Muslim

2. Hadits yang melarang mu'amalah dalam bentuk jual beli.

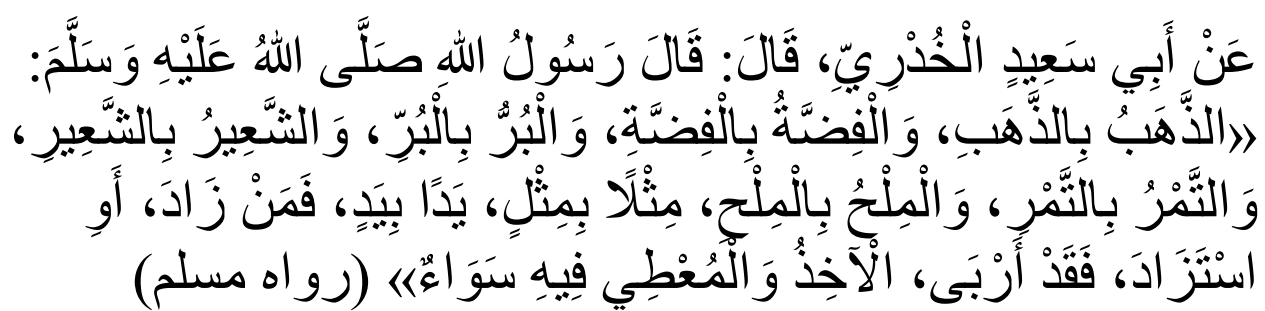

"Diriwayatkan oleh Abu Said Al Khudri bahwa Rasulullah saw. bersabda,n"Emas hendaklah dibayar dengan emas,perak dengan perak, gandum dengan gandum, tepung dengan tepung, kurma dengan kurma, garam dengan garam, bayaran harus dari tangan ke tangan (cash). Barang siapa memberi tambahan atau meminta tambahan, sesungguhnya ia telah erurusan dengan riba. Penerimadan pemberi sama-sama bersalah." (HR. Muslim)

Berjual beli emas, perak dan bahan-bahan makanan pokok dengan jenis ti dibolehkan dengan syarat harus sama dan harga tunai, dengan maksud agar pintu muamalah ribawiyah ditutup dengan secepat-cepatnya. Sebab jual beli emas, perak dan bahan-bahan makanan pokok dengan jenis itu terjadi bila salah satu pihak akan memperoleh keuntungan. Untuk menjaga agar mencari keuntungan itu jangan sampai berakibat pada salah satu pihak, padahal dalm menyangkut bahan-bahan yang benarbenar kebutuhan hidup sehari-hari, maka diadakan ketentuan bahwa antara barangbarang sejenis yang dijual belikan itu harus sama banyaknya dan harus tunai pula. 
3. Hadits tentang riba dan utang-piutang

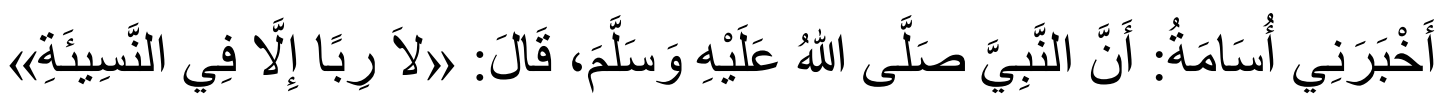
Dari Usamah r.a bahwasannya Nabi shallalahu 'alaihi wa sallam bersabda: tidak terjadi kecuali dalam nasi'ah.” (H.R Bukhari)

Dari hadits ketiga ini diperoleh penerangan bahwa riba hanya terjadi dalam nasi'ah, yaitu utang piutang bertangguh waktu dengan syarat dalam perjanjian adanya tambahan dalam pembayaran. Hadits yang membatasi terjadinya riba hanya dalam utang piutang tersebut nampak ada pertentangan dengan hadits-hadits yang mengajarkan terjadinya riba dalam jual beli tunai dengan syarat terjadi tambahan antara barang-barang sejenis yang disebut riba fadhl.

4. Hadits yang melarang muamalah tertentu karena mengandung unsur ribawi.

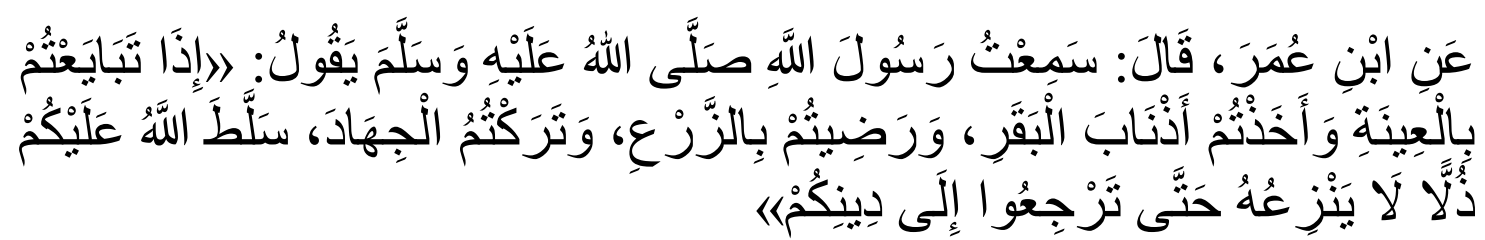

Dari Ibnu 'Umar r.a berkata : saya mendengar Rasulullah Saw, bersabda "Apabila kalian berjual beli secara 'ainah dan kalian hanya repot pekerjaan dan bersenang dengan bertani saja, sambil meninggakan jihad, pasti Allah akan membuat kalian dikuasai oleh kehidupan yang tidak dapat mencabutnya kehinaan itu sesuatupun, sehingga kalian kembali pada perintah agama kalian.” (H. R. Abu Daud).

\section{Konsep Bunga Bank dalam Islam}

Bunga merupakan tanggungan pada pinjaman uang, yang biasanya dinyatakan dengan persentase dari uang yang dipinjamkan. Kemudian apakah bunga termasuk riba, ada dua pendapat; pertama, menurut ijma ulama di kalangan semua mazhab fiqh bahwa bunga dengan segala bentuknya termasuk kategori riba. Dan kedua, pendapat yang menyatakan bahwa bunga tidak termasuk kategori riba.

Di era modern, bank hadir menjadi pusat penggerak perekonomian manusia secara global. Banyak sekali persoalan muncul terkait sistem bank dan mengerucut terutama pada hukum bunga bank dalam Islam. Ada berbagai pendapat mengenai bunga bank, ada yang berpendapat bahwa bunga bank itu diperbolehkan pada persoalan tingkat 
bunga, pada tingkat yang wajar maka bunga dibolehkan. Dalam tafsir al-Manar, Abduh (dalam Nasution, 1996) dan di dalam fatwa-fatwanya, sebagaimana dicatat 'Ammarah, menyebutkan bahwa Muhammad Abduh membolehkan menyimpan uang di bank dan juga boleh mengambil bunga simpanannya, dengan kata lain ia mehalalkan bunga bank. Hal ini menurutnya, didasarkan pada maslahah-mursalah (kesejahteraan). Larangan riba menurut Muhammad Abduh adalah untuk menghindari adanya unsur eksploitasi dan menghindari memakan harta orang lain secara batil (al-Baqarah : 188) (Salam, 2013). Namun tingkat bunga wajar sangat subjektif tergantung pada waktu, tempat, jangka waktu, jenis usaha dan skala usaha (Kalsum, 2014). Aspek ini juga terdapat pada ayat pelarangan riba tahap ketiga yang terdapat pada Q.S. Ali Imran [3]: 130 merupakan ayat pertama yang menyatakan secara tegas terhadap pengharaman riba bagi orang Islam. dan adapun yang berpendapat bahwa bunga bank itu diharamkana secara tegas.

Pada tahapan justifikasi system bunga yang konvensional, ada sementara orang berdalih bahwa riba yang diharamkan Allah dan Rasul-Nya, adalah jenis yang dijenal sebagi bunga konsumtif. Yaitu, bunga yang khusus dibebankan bagi orang yang berutang untuk memenuhi kebutuhan hidupnya sehari-hari, seperti makan, minum dan melengkapi pakaiannya yang berada dalam tanggungannya. Hal ini terjadi karena dalam jenis riba tersebut terdapat unsur pemerasan (eksploitasi) terhadap kepentinan orang yang sedang membutuhkan. Karena itu, ia terpaksa meminjam. Namun, si pemilik uang menolak untuk memberi pinjaman, kecuali dengan riba (bunga), agar jumlah uang yang dikembalikan nanti bertambah .

Fakta sejarah membantah penafsiran salah seperti ini. Karena jenis riba yang terjadi pada hari ini adalah riba komersial. Dalam perekonomian modern, pada dasarnya bank adalah lembaga perantara dan penyalur dana antara pihak yang berkelebihan dana dengan pihak yang kekurangan dana. Peran ini disebut "Financial Intermediary". Dalam melaksanakan tugasnya yang paling menonjol sebagai financial intermediary itu, bank dapat dikatakan membeli uang dari masyarakat pemilik dana ketika ia menerima simpanan, dan menjual uang kepada masyarakat yang memerlukan dana ketika ia memberi pinjaman kepada mereka. Dalam kegiatan ini muncul apa yang disebut bunga. Sri Edi Swasano, seorang pakar muslim dalam disipilin ilmu ekonomi, berpendapat P-ISSN : 2460-9595 
62 | Annisa Eka Rahayu, Nunung Nurhayati, TELAAH KRITIS PEMIKIRAN ABdUL MANNAN TENTA........... bahwa bunga adalah harga uang dalam transaksi jual-beli tersebut. Dengan demikian, bunga yang ditarik oleh bank dari pemakai jasa, merupakan ongkos adminitrasi dan ongkos sewa. Sehingga dari sini kelihatan bahwa penyimpanan uang di bank akan mendapat bagian keuntungan dari bank berupa bunga yang diambilkan dari bunga yang diterima oleh bank. Argumen lainnya yang menyatakan bahwa karena bunga yang diberikan oleh institusi keuangan saat ini tidak sama dengan riba yang dipraktekkan pada zaman jahiliah. Tetapi argumen ini, tidak mampu menggoyangkan pendapat para fuqaha dan mayoritas ekonom muslim modern yang menjunjung konsensus historis tentang riba, yang banyak mendapat dukungan.

Untuk itu Islam sebagai agama rahmatan lil'alamin, berusaha melalui para pakar muslim yang berkecimpung dalam dunia ekonomi untuk memberikan solusi terhadap sistem bunga bank, yaitu dengan mendirikan bank Islam, di mana prinsip yang dipakai dalam bank Islam ini adalah tidak didasarkan pada sistem bunga, melainkan lewat sistem bagi hasil. ementara bank Islam menetukan keuntungan menurut laba yang telah diperoleh. Kedua belah pihak sama-sama menanggung untung dan rugi. Keuntungan bisa naik atau turun tergantung kepada besar kecilnya laba yang diperoleh. Kepada peminjam, bank Islam tidak menentukan bunga dan kepada penabung tidak memberikan bunga, yang diberikan adalah keuntungan yang diperhitungkan atas dasar besar kecilnya laba yang didapat.

\section{Pemikiran Muhammad Abdul Mannan Terkait Riba dan Bunga Bank}

Agar dapat memberikan jawaban mengenai apakah riba (al-ribâ) dan bunga itu sama, orang harus mengerti arti Riba dalam perspektif sejaranhnyayang tepat. Arti bebas istilah ini adalah pertambahan atau pertumbuhan, setiap pertumbuhan seperti halnya pertambahan yang berasal dari perdagangan dan industri tidaklah dilarang (Mannan, 1997). Riba juga mengacu pada perbuatan mengambil sejumlah uamh yang berasal dari orang yang berutang, secara berlebihan. Hal ini, sering dilakukan oleh orang Arab jahiliyah. Banyak macam riba yang terjadi di kalangan orang Arab ketika itu, yang sering disebut dengan riba jahiliyah. 
Riba jahiliyah adalah bila pada suatu ketika seseorang memberikan pinjaman untuk suatu jangka waktu tertentu dan bila periode itu telah habism si pemberi akan menagih dan si peminjam mengembalikan utangnya dengan menaikkan jumlahnya. Jikaia membayarnya, akan diterima, kalau tidak maka jumlah utang itu akan bertambah sesuai perpanjangan waktu. Begitulah pengertian riba jahiliyah, para ulama sepakat bahwa yang dimikian itulah definisi riba pra-Islam, yakni perpanjangan batas waktu dan penambahan jumlah uang sehingga berjumlah begitu besar, sehingga pada akhir waktu pinjaman itu, si peminjam akan mengembalikan kepada orang yang meminjamkan sejumlah dua kali lipay dari jumlah pokok yang dipinjamkannya.

Sekarang mari berbicara mengeai bunga. Haberler dalam karyanya Prosperity and Depressions telah menyatakan dengan tepat, bahwa,"Penjelasan dan penentuan di antara para ahli ekonomi, mengenai suku bunga masihbsaja menimbulkan lebih banyak pertentangan di antara para ahli ekonomi”. Selanjutnya, menurut Mannan bahwa teoriteori tentang bunga tidak dapat menjawab pertanyaan "bunga mengapa dibayarkan". Tetapi konsesus pendapat menganggap bahwa bunga merupakan tambahan tetap bagi modal. Dikemukakan bahwa tambahan yang tetapn ini merupakan biaya yang layak bagi digunakannya yang dalam suatu proses produksi. Menyebut riba dengan bunga bank yang tidak mengubah sifatnya. Kenyataan hal itu adalah bahwa istilah ekses harus diambil dalam arti yang relative, karena apa yang merupakan ekses layak hari ini, mungkin akan dianggap suku bunga yang luar biasa tinggi atau bersifat riba pada hari esok.

Selanjutnya, tidaklah tepat untuk mengatakan bahwa pada masa pra-Islam pinjaman tidak diebrikan untuk tujuan produksi. Mannan, memiliki catatan yang menunjukkan bahwa Yahudi-Madinah meminjamkan uang tidak hanya untuk konsumsi, tetapi juga untuk perdagangan. Adanya mudhârabah pada waktu atau persekutuan diam-diam di kalanga Arab tidak menunjukkan kenyataan bahwa bunga yang produktif tidak sedang digemari di kalangan mereka. Pada kenyataan perbedaan antara pinjaman produktif dengan yang tidak produktif adalah perbedaan dalam tingkatan. Jika bunga yang terjadi pada pinjaman konsumsi berbahaya, maka bunga pinjaman produktif pun tentu berbay=haya jugam karena ia merupakan biaya produksi, dank arena itu P-ISSN : 2460-9595 
memengaruhi harga. Karena itu, dalam analisis terakhir dapat dikatakan bahwa riba dalam AL-Qur'an dan bunga pada perbankan modern merupakan dua sisi dari mata uang yang sama.

Telaah Kritis terhadap Pemikiran Muhammad Abdul Mannan terkait Riba dan Bunga Bank

Dengan memperhatikan pendapat di atas, maka menurut analisis penulis bahwa bunga uang atau bunga bank termasuk riba. Bunga uang dapat mencekik kalangan ekonomi atau pengusaha kecil, mereka ambil kredit dengan harapan usahanya dapat tumbuh dan berkembang. Namun karena bunga yang tiap bulan harus dibayar maka usahanya bukan saja tidak bias berkembang bahkan akhirnya gulung tikar. Itulah sebabnya sebagian ulama mengharamkan sistem bunga dan dinyatakan sebagai riba. Menurut analisis penulis bahwa pendapat Mannan seperti telah dijelaskan lebih dahulu sesuai dengan al-Qur'an dan hadis yang mengharamkan riba. Persoalan tentang riba yang dilarang bukan saja dibicarakan dalam agama Islam tetapi juga dalam agamaagama samawi lainnya. Bahkan sejak zaman kejayaan Athene, Solon telah membuat undang-undang yang melarang bunga.

Ahli-ahli filsafat seperti Plato dan Aristoteles pun tidak membenarkan riba. Mereka menganggap bunga uang bukan keuntungan yang wajar karena pemilik uang tersebut tidak turut serta menanggung resiko. Mannan berpegang kepada dalil al-Qur'an surah al-Baqarah [2]: 275-276, 278-279 yang isinya tentang pelarangan riba secara tegas dan jelas, dalam berbagai bentuknya tidak dibedakan besar atau kecilnya dan tidak membedakan banyak atau sedikitnya. Bagi yang melakukannya maka ia telah mekakukan tidakan kriminalisasi. Dan ini adalah merupakan ayat yan terakhir turun, yang merupakan syariat yang terakhir pula. Dalam ayat ini jika seseorang melakukan transaksi riba, makan Allah dan Rasul-Nya akan memerangi orang tersebut.

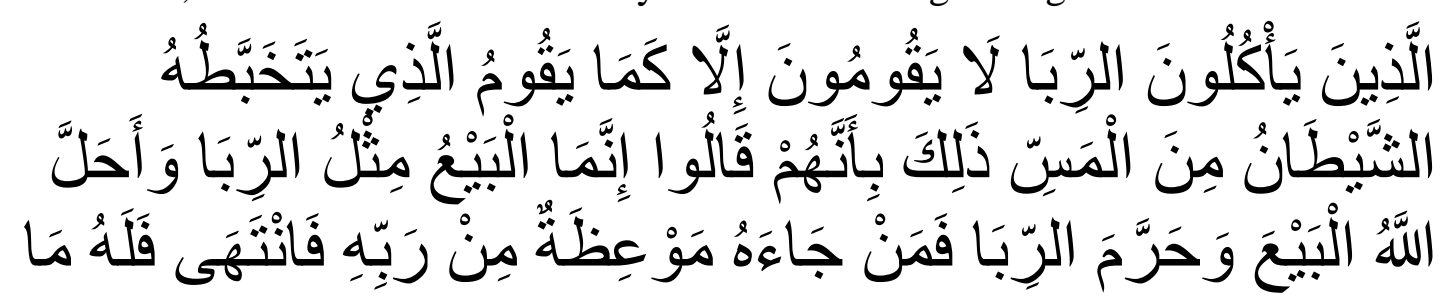


ISLAMIC BANKING: Jurnal Pemikiran dan Pengembangan Perbankan Syariah, Volume 6 Nomor 1 Edisi Agustus $2020 \mid 65$

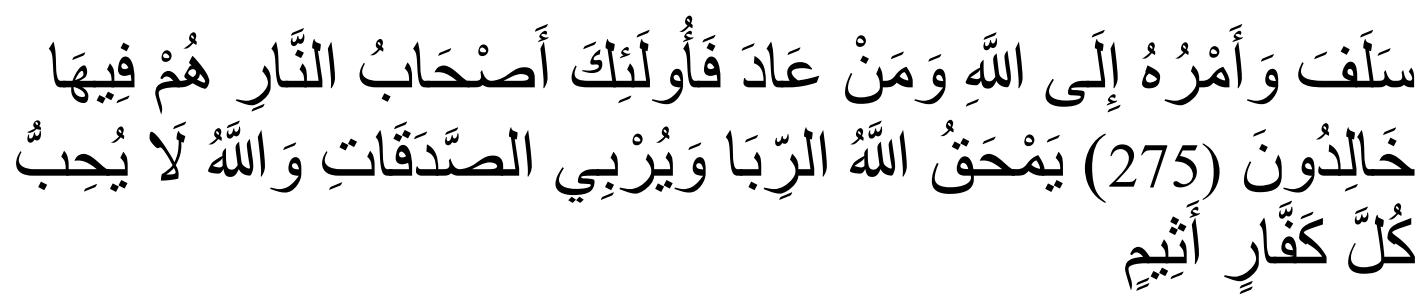

"Orang-orang yang makan (mengambil) riba tidak dapat berdiri melainkan seperti berdirinya orang yang kemasukan syaitan lantaran (tekanan) penyakit gila. Keadaan mereka yang demikian itu, adalah disebabkan mereka berkata (berpendapat), sesungguhnya jual beli itu sama dengan riba, padahal Allah telah menghalalkan jual beli dan mengharamkan riba. Orang-orang yang telah sampai kepadanya larangan dari Tuhannya, lalu terus berhenti (dari mengambil riba), maka baginya apa yang telah diambilnya dahulu (sebelum datang larangan); dan urusannya (terserah) kepada Allah. Orang yang mengulangi (mengambil riba), maka orang itu adalah penghuni-penghuni neraka; mereka kekal di dalamnya.(275) Allah memusnahkan riba dan menyuburkan sedekah. Dan Allah tidak menyukai setiap orang yang tetap dalam kekafiran, dan selalu berbuat dosa.(276)" (Q.S. al-Baqarah [2] : 275-276).

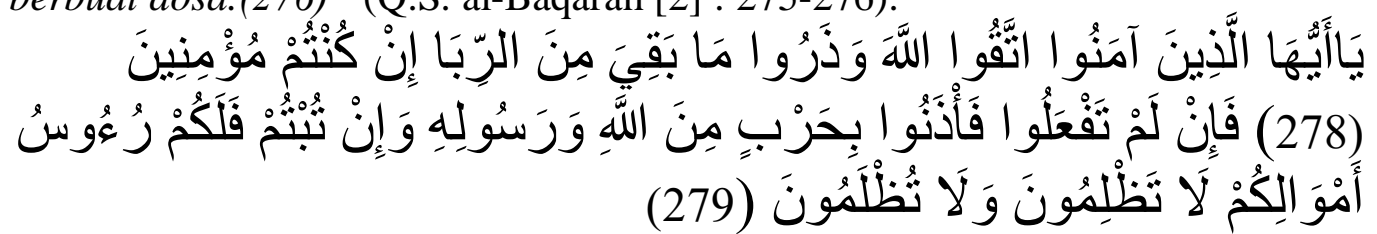

"Hai orang-orang yang beriman, bertakwalah kepada Allah dan tinggalkan sisa riba (yang belum dipungut) jika kamu orang-orang yang beriman. Maka jika kamu tidak mengerjakan (meninggalkan sisa riba), maka ketahuilah, bahwa Allah dan Rasul-Nya akan memerangimu. (278). Dan jika kamu bertobat (dari pengambilan riba), maka bagimu pokok hartamu; kamu tidak menganiaya.

Menurut penulis, illat hukum keharaman riba al-nasi'ah adalah kelebihan pembayaran dari pokok hutang yang ditunda pembayarannya pada waktu tertentu. Misalnya, Umar berhutang kepada Amir sejumlah dua ratus ribu rupiah, yang pembayarannya dilakukan bulan depan dan dengan syarat pengembalian hutang itu dilebihkan menjadi dua ratus lima puluh ribu rupiah. Kelebihan uang dengan tenggang waktu ini disebut dengan riba al-nasi'ah. Unsur kelebihan pembayaran dapat berlipat ganda, apabila hutang tidak dapat dibayar pada saat jatuh tempo, menurut ulama Hanafiyah, merupakan suatu kezaliman dalam muamalah. Kezaliman, bagaimanapun bentuknya, menurut mereka adalah haram. Setidaknya ada beberapa alasan mengenai 
66 | Annisa Eka Rahayu, Nunung Nurhayati, TELAAH KRITIS PEMIKIRAN ABDUL MANNAN TENTA........... pengharaman riba (H. Aravik, 2018). (a) Riba adalah mengambil harta orang lain tanpa nilai imbalan apa pun. Padahal, menurut Rasulullah SAW harta seseorang adalah seharam darahnya bagi orang lain. (b). Riba dilarang karena menghalangi manusia untuk terlibat dalam usaha yang aktif. (c). Kontrak riba adalah media yang digunakan orang untuk mengambil kelebihan dari modal. Perbuatan ini haram dan bertentangan dengan keadilan dan persamaan. (d). Kontrak riba memunculkan hubungan yang tegang di antara sesama manusia. (e). Keharaman riba dibuktikan dengan ayat al-Qurean, dan seseorang tidak perlu tahu alasan pengharamannya. Karena tujuan syariah sendiri yaitu meginginkan setiap individu sejahtera menggunakan istilah mashlahah (F. Z. dan H. Aravik, 2019).

\section{Simpulan}

Berdasarkan hasil uraian di atas, dapat disimpulkan bahwa riba dan bunga bank merupakan satu kesatuan yang tidak dapat dipisahkan. Kata lain bunga bank, tidak akan mengubah makna "riba" itu sendiri. Begitu pula penafsiran Muhammad Abdul Mannan seornag tokoh ekonom kontemporer berpendapat bahwa bunga bank sama saja dengan riba, baik itu bunga konsumtif maupun bunga produktif. Penulis memiliki pemahaman yang sama dengan Muhammad Abdul Mannan, yang mana bunga bank dan riba adalah sama-sama haram. 
ISLAMIC BANKING: Jurnal Pemikiran dan Pengembangan Perbankan Syariah, Volume 6 Nomor 1 Edisi Agustus 2020 | 7

\section{DAFTAR PUSTAKA}

Adam, N. N. dan P. (2015). Hukum Perbankan Syari'ah: Konsep dan Regulasi. Sinar Grafika.

Adam, P. (2017). Hukum Perbankan Syariah. Refika Aditama.

Al-Zuhaili, W. (2009). Al-Fiqh al-Islam wa Adillatuh. Dar al-Fikr.

Antonio, M. S. (2007). Bank Syariah: Dari Teori ke Praktik. Gema Insani dan Tazkia Cendikia.

Aravik, F. Z. dan H. (2019). Perekonomian Islam. Kencana.

Aravik, H. (2017). Sejarah Pemikiran Ekonomi Islam. Kencana.

Aravik, H. (2018). Pemikiran Ekonomi Sayyid Qutb. Jurnal Islamic Banking Volume, III, 40.

Aravik, H. (2020). Filsafat Ekonomi Islam: Ikhtiar Memahami Nilai Esensial Ekonomi Islam. Kencana.

Ash-Shabuni, M. A. (2016). Tafsir Ayat-Ayat Ahkam. Keira Publishing.

Badri, M. A. (2018). Riba dan Tinjauan Kritis Perbankan Syariah. Pustaka Dhiya'ul Ilmi,.

Ghofur, A. (2016). Konsep Riba Dalam Al-Qur'an. Jurnal Economica, VII, 1.

Hakim, C. M. (2011). Belajar Mudah Ekonomi Islam: Catatan Krisis Terhadap Dinamika Perkembangan Perbankan Syariah di Indonesia. Shuhuf Media Insani.

Haneef, M. A. (1995). Contemporary Islamic Economic Thought a Selected Comparative Analysis. Selangor.

Haneef, M. A. (2010). Pemikiran Ekonomi Islam Kontemporer: Analisis Komparatif Terpilih. RajaGrafindo Persada.

Janwari, Y. (2016). Pemikiran Ekonomi Islam: Dari Masa Rasulullah Hingga Masa Kontemporer. Rosda.

Kalsum, U. (2014). Riba Dan Bunga Bank Dalam Islam (Analisis Hukum Dan Dampaknya Terhadap Perekonomian Umat). Al- 'Adl, 7, 71.

Khair, I. Ak. A. (2017). Hidup Nyaman Tanpa Riba. Pustaka al-Inabah.

Mamudji, S. S. \& S. (2018). Penelitian Hukum Normatif; Suatu Tinjauan Singkat. Rajawali Press.

Mannan, M. A. (1997). Teori dan Praktik Ekonomi Islam. : PT. Dana Bhakti Prima Yasa.

Muhamad. (2019). Sejarah Pemikiran Ekonomi Islam: Ekonomi, Manajemen, P-ISSN : 2460-9595

DOI. 10.36908/isbank 
68 | Annisa Eka Rahayu, Nunung Nurhayati, TELAAH KRITIS PEMIKIRAN ABDUL MANNAN TENTA.......... Keuangan, Bank dan Akuntansi. UII Press.

Mukaromah, O. (2004). Interpreasi Ayat-Ayat Riba dalam Kajian Tafsir Maudhu'i. AlQalam, 21, 83.

Nawawi. (2019). Teori Fikih Ekonomi. Literasi Nusantara.

Qardhawi, Y. (2002). Bunga Bank Haram. Akbar Media Eka Sarana.

Rozalinda. (2016). Ekonomi Islam Teori dan Aplikasinya Pada Aktivitas Ekonomi. RajaGrafindo Persada.

Salam, A. (2013). Bunga Bank Dalam Perspektif Islam (Studi Pendapat Nahdlatul Ulama Dan Muhammadiyah). Ekonomi Syariah Indonesia, III.

Sobana, D. H. (2018). Manajemen Keuangan Syari'ah. Pustaka Setia.

Zuhri, M. (1997). Riba dalam Al-Qur'an dan Masalah Perbankan (Sebiah Tilikan Antisipatif). RajaGrafindo Persada. 